\title{
KALBA
}

\section{PARLAMENTARŲ VIEŠOSIOS SAKYTINĖS KALBOS PROBLEMATIKA}

\author{
DR. Vida RudaItienE்
}

Mykolo Romerio universiteto Humanitariniu mokslu instituto Kalbos kultūros katedra Mykolas Romeris University Institute of Humanities

Department of Language Culture

Ateities g. 20, LT-08303 Vilnius

El.paštas rudaitiene@mruni.eu

\section{Santrauka}

Straipsnyje nagrinèjama parlamentaru viešoji sakytinè kalba. Iškeliama anglu kalbos, kaip vieno iš svarbiausiu globalizacijos veiksnių, sustiprèjusi įtaka lietuviu kalbai, jos leksikai, ypač skoliniu vartojimo tendencijoms. Aptariami ryškesni tarptautiniu žodžiu ir apskritai skoliniu vartojimo polinkiai įstatymu leidejų viešojoje sakytineje kalboje. Nagrinejjami neteiktini vertiniai, gramatinès formos: morfologiniu bei darybos formu, sintaksès formu, ypač linksniu ir prielinksniu, vartojimas. Seimo nariu viešoji sakytine kalba vertinama bendrinès lietuviu kalbos normu ir kalbos etikos atžvilgiu. Pagrindinis kalbos duomenu šaltinis - parlamentaru viešoji sakytinè kalba: dažniausiai per Lietuvos televizija, radiją transliuojami Seimo posėdžiai, ịvairiu politinių diskusiju, komentaru, pokalbiu laidos, konferencijos ir kt.

Reikšminiai žodžiai: ekstralingvistiniai veiksniai; interlingvistiniai veiksniai; skolinys; tarptautinis žodis; kalbos etika; konotacinè reikšmė. 


\section{Ivadas}

Kiekviena epocha, kiekviena žmonių karta formuoja ir veikia lietuvių kalbą. Daugelis ekstralingvistinių veiksnių turi įtakos lietuvių kalbos raidai. Intensyvūs globalizacijos procesai, visuomenès raida, įvairūs politiniai ir ekonominiai pokyčiai veikia ir parlamentarų viešąą sakytinę kalbą. Akivaizdu, kad lietuvių kalba nekelia pasididžiavimo jausmo, dažnai puikuojamasi ne savo, o svetimų kalbų mokejjimu. Pavyzdžiui, įsimintinas ir toks atvejis. Per prezidento rinkimų kampaniją $2009 \mathrm{~m}$. Lietuvos nacionalinė televizija transliavo laidą „Redakcija“, kurios metu prisistatè kandidatai ì prezidentus. Laidų vedèjai labai akcentavo kitų kalbų, ypač anglų kalbos, mokejjimą. Pagrindinis klausimas būsimam prezidentui: „Ar turite problemu su anglu kalba?" (= Ar turite sunkumų dèl anglų kalbos?). Bet nè vienas laidos vedèjas neatkreipè dèmesio ị daugelio norinčių būti prezidentu lietuvių kalbos, valstybinès kalbos, prastą mokejjimą, akivaizdų bendrinès lietuvių kalbos normų nepaisymą. Tik Seimo narys Arūnas Valinskas laiku ir vietoje pareiškè: „Prezidentas turi gerai, gražiai kalbèti lietuviškai.“ (LTV, „Redakcija“, 2009-03-16). Reikètų suprasti, kad ignoruojant gimtąją lietuvių kalbą prisidedama ir prie žmonių, ypač jaunosios kartos, dorovinès kultūros nuosmukio. Apskritai visuomenèje ịsigali vartotojiška kalbos samprata - lietuvių kalba verčiama paprasčiausia bendravimo priemone. Jei kalba verčiama tik bendravimo priemone, t. y. svarbu tik susikalbèti, ji neatlieka savo kultūrinès funkcijos. Be to, lietuvių kalbos vertinimas atsispindi ir kiekvieno jos vartotojo kalboje. Sąmoningas lietuvių kalbos vartotojas suvokia ne tik apie ką kalbama, bet ir kaip kalbama. Blogiausia, kad lietuvių kalba nevertinama kaip asmens kultūros raiška, kaip apskritai kultūros pagrindas. Vis dèlto mūsų požiūris ị lietuvių kalbą, jos vertinimas taip pat yra mūsų kultūros dalis. 
Be to, ryškus noras, kuriam neatsispiria ir dalis Seimo narių, išsiskirti iš kitų ir su tuo susijęs kalbos moderninimas, siekimas kalbèti neịprasčiau, kitoniškai.

Pastebimas ir tam tikru laikotarpiu vienų ar kitų leksikos vienetų itin dažnas vartojimas. Radosi ir reiškinys kalbos mada. Vertinant lietuviškus ir svetimų kalbų žodžius, jų vartoseną, kai kuriuos iš jų galima įvardyti ir kaip madinguosius elementus. Bet kalbos mada negali būti priežastis įteisinant vienų ar kitų žodžių vartojimą.

Vykstant globalizacijai, parlamentarų viešajai sakytinei kalbai, kaip ir apskritai lietuvių kalbai, turi ittakos ir interlingvistiniai veiksniai. Pastaruoju metu ryški anglų kalbos ịtaka. İstatymų leidejų viešojoje sakytinejje kalboje jau matyti vertimų iš anglų kalbos poveikis. Per anglų kalbą, dažniausiai per vertimus, ateina daug leksikos skolinių, dalis jų pradeda îsigalèti ir kaip terminai. Leksikos skoliniams, paprastai seniai lietuvių kalboje vartojamiems tarptautiniams žodžiams, suteikiama ir naujų reikšmių, būdingų anglų kalboje vartojamų atitinkamų žodžių reikšmėms. Ir savi lietuviški žodžiai kartais iškraipomi nusižiūrèjus ị angliškus žodžius. Parlamentarų viešojoje sakytineje kalboje daugèja ir vertinių iš anglų kalbos. Anglų kalba veikia ir žodžių darybą, įvairių gramatinių formų vartojimą, sakinių struktūrą, jų modelius. Taigi Seimo narių viešąją sakytinę kalbą vienaip ar kitaip veikia anglų kalba.

Straipsnio tikslas - paanalizuoti parlamentarų viešąją sakytinę kalbą; aptarti vartojamą lietuvių kalbos ir svetimų kalbų leksiką, jos vartosenos pokyčius, iškelti šiuos pokyčius lemiančius svarbesnius ekstralingvistinius ir interlingvistinius veiksnius; panagrinėti anglų kalbos, kaip vieno iš globalizacijos veiksnių, ittaką leksikos, ypač skolinių vartojimo tendencijoms; paanalizuoti neteiktinus vertinius, gramatinių formų: sintaksès, morfologijos, žodžių darybos ryškesnes vartojimo negeroves; įvertinti parlamentarų viešąją 
sakytinę kalbą ne tik bendrinès lietuvių kalbos normų, bet ir kalbos etikos atžvilgiu. Taip pat vienas iš keliamų tikslų - skatinti Seimo narius puoselèti lietuvišką žodị, kelti lietuvių kalbos prestižą.

Tyrimo metodai - empirinis, analitinis. Remtasi naujausiais, t. y. 2009-2012 metų stebejjimais.

Pagrindinis kalbos duomenų šaltinis - parlamentarų viešoji sakytinẻ kalba, dažniausiai per Lietuvos televiziją transliuojamus Seimo posėdžius (per „Init“, kartais per LTV kanalus), per Lietuvos radiją ir televiziją transliuojamas politinių diskusijų, komentarų, pokalbių, konferencijų ir kt. laidas. Sakytinė kalba yra patikimesnis šaltinis realiai kalbos vartosenai atskleisti, nes rašytine paprastai jau būna paveikta redaktorių, stilistų. Kita vertus, vieni ar kiti kalbos faktai iš sakytinès kalbos plinta ị rašytinę ir atvirkščiai. Nurodomas televizijos ir radijo kanalas, per kurị iš vienos ar kitos transliuojamos laidos paimtas analizuojamas kalbos faktas. Vartojamos iprastos televizijos kanalų santrumpos. Lietuvos radijo santrumpa - LR. Skaičiai rodo datą, kada buvo išgirstas nagrinėjamas kalbos faktas. Iliustraciniai sakiniai dažniausiai sutrumpinti.

Parlamentarų viešoji sakytinè kalba yra aktuali problema. Nes Seimo nariai dažnai viešai kalba. Jų sakytinè kalba veikia visuomenės, ypač jaunimo kalbą, turi įtakos apskritai bendrinei lietuvių kalbai. Politikų kalbos reikšmè vertinama nuo antikos laikų. Politikų viešoji kalba vienu ar kitu aspektu tyrinėjama, vertinama ir šiomis dienomis. Tai rodo ir patys naujausi moksliniai darbai. Regina Koženiauskienẻ Lietuvos parlamentarų retoriką vertina etiniu požiūriu ir turi tikslą „parodyti, kad etika yra svarbiausias kalbejjimo matas, nusveriantis visus kitus vertybinius kriterijus - sklandžią, skambią frazeologiją, tropus ar figūras"1. Kazimieras Župerka remdamasis nedidelès apklausos duomenimis pateikia sąrašą žymių

${ }^{1}$ Koženiauskienè, R. Politinè retorika etiniu požiūriu. Parlamento studijos. Vilnius: Lietuvos nacionalinė Martyno Mažvydo biblioteka, 2005, Nr. 3, p. 110-121. 
Lietuvos žmonių, tarp jų ir žinomų politikų, Lietuvos Respublikos Seimo narių, kuriuos apklaustieji priskyrè elitiniam kalbos tipui². Lauras Bielinis lingvistiniu požiūriu nagrinèja politinès komunikacijos situaciją ${ }^{3}$, Laura Butkute - frazeologinių junginių stilistinę raišką politikų kalboje $e^{4}$ Nagrinètos ir skolinių vartojimo tendencijos politiniame diskurse ${ }^{5}$ ir kt.

Nemažos dalies Seimo narių viešoji sakytinè kalba yra palyginti taisyklinga, aiški, suprantama. Deja, yra parlamentarų, kurie visiškai nesilaiko bendrinès lietuvių kalbos normų, taip sugeba sujaukti sakinį, kad lieka neaišku, kas norèta pasakyti. Taip rodoma ir nepagarba valstybinei lietuvių kalbai, įteisintai Lietuvos Respublikos Konstitucijos. Prezidentas Antanas Smetona buvo itin griežtas visiems, ypač valdžios žmonėms, žalojantiems lietuvių kalbą. Jis teigè, kad „kalba turi būti rūpestingai ugdoma iš tautos lobyno, iš jos tarmių, o ne iš prasimanymo. Būdama graži ir tyra, ji didele galybè. $<\ldots>$ Taigi kiekvienas, kuris ruošiasi vienoje ar kitoje srityje vadovauti, privalo gerai mokèti lietuvių kalbos ir literatūros. Jei nemokès, tai bevadovaudamas dirbs nutautinimo darbą“6.

${ }^{2}$ Župerka, K. Elitine kalba ir jos atstovai. Parlamento studijos. Vilnius: Lietuvos nacionalinè Martyno Mažvydo biblioteka, 2005, Nr. 4, p. 144-158.

${ }^{3}$ Bielinis, L. Lingvistiniai politinès komunikacijos supratimo aspektai. Respectus philologicus. Kaunas: Vilniaus universiteto Kauno humanitarinio fakulteto leidykla, 2002, Nr. 2, p. 49-59.

${ }^{4}$ Butkute, L. Frazeologinių junginių stilistinė raiška Seimo stenogramose. Parlamento studijos. Vilnius: Lietuvos nacionalinè Martyno Mažvydo biblioteka, 2009, Nr. 8, p. 169-178.

${ }^{5}$ Rudaitienè, V. Skolinių vartojimo tendencijos politiniame diskurse. Lituanistika. Vilnius: Lietuvos mokslų akademijos leidykla, 2003, Nr. 1, p. 62-74; Rudaitiené, V., Račienè, E. Globalisierung und lexikalische Entlehungen im politischen Diskurs. Baltische Studien zur Erziehungs- und Sozialwissenschaft. Frankfurt am Main: Peter Lang, 2011, band 22, p. 431-446.

${ }^{6}$ Smetona, A. Rinktiniai raštai. Sudare [ir pratarmę, p. 5-8, parašè] Alfonsas Eidintas. Kaunas: Menta, 1990, p. 386. 


\section{Anglų kalbos žodžiai ir jų lietuviški atitikmenys}

Parlamentarų viešojoje sakytineje kalboje pastebima ir anglų kalbos žodžių, vartojamų vietoj lietuviškų arba ịprastų tarptautinių žodžių, pvz.: Barteriniai (= Natūriniai) mainai materialiojo turto apskaitoje neimanomi LNK 2010-04-07; Kitais metais mes galime patirti defaulta (= nemokumą), valiutos devalvavima "Lietuvos ryto" tv 2010-01-24; Reikia matyti partiju siūlymų draftą (= planą, projektą) "Lietuvos ryto" tv 2010-01-24; Jūs [kreipimasis ị aplinkos apsaugos ministrą] ne statybų menedžeris (= vadybininkas), bet politikas LTV 2011-03-29; Dalis įmonių įregistruotos ị ofšorus (= laisvąsias ekonomines zonas; lengvatinių mokesčių, neapmokestinamas, lengvatinès prekybos įmones, zonas) LTV 2009-02-24; Bankai nutrauke overdraftus (= kredito perviršius) „Init“ 2009-07-14; Per visus samitus (= vadovų susirinkimus) mes visuomet jautème Lenkijos prezidento L. K. parama LTV 2010-04-12.

Kai kurie parlamentarai vartoja ir neteiktinų santrumpų, padarytų iš anglų kalbos žodžių. Viena iš dažnesnių - piaras, padarytas iš anglų kalbos žodžių junginio public relations, kurio lietuviški atitikmenys yra ryšiai su visuomene, viešieji ryšiai, t. y. visuma būdų, kaip save pateikti (¿̨vaizdžio kūrimas), pvz.: Per rinkimų kampanija suintensyvès piaras (= viešieji ryšiai; ryšiai su visuomene) LTV 2012-02-01. Šios santrumpos polinkị įsitvirtinti vartosenoje rodo ir tai, kad iš jos padarytas būdvardis su priesaga -inis, -ie, pvz.: Atmetème visus piarinius (= viešųjų ryšių) klausimus LTV 2011-11-21. Nueita dar toliau - iš santrumpos piaras padarytas ir veiksmažodis piarinti, pvz.: Jei kiekvienas Seimo narys nusisamdys žurnalistą, kuris jị piarins (= kurs jo ịvaizdị; rūpinsis jo viešaisiais ryšiais; reklamuos), bus visiška nesąmone „Lietuvos ryto“ tv 2010-04-03.

Kartais pavartojamas ir savotiškas darinys imidžmeikeris - ịvaizdžio kūrèjas, pvz.: Darbo partija stiprins imidžmeikerių (= ịvaizdžio 
kūrèjų) komandą, kad mūsų kandidatè i prezidentes neatrodytų prasčiau už Vokietijos, JAV ir kitu valstybių kandidates TV3 2009-03-22.

\section{Tarptautinių žodžių vartojimo tendencijos}

Parlamentarų viešojoje sakytinejje kalboje, kaip ir apskritai bendrinejje lietuvių kalboje, gausèja ir tarptautinių žodžių. Tarptautiniai žodžiai, arba internacionalizmai, laikomi bendrinei lietuvių kalbai priimtinais skoliniais. Jie formaliai yra prisiderinę prie lietuvių kalbos fonetikos, gramatikos, rašybos dėsnių. Lietuvių kalboje tarptautinių žodžių vartojimas priklauso nuo funkcinio stiliaus. Blogybè ta, kad tarptautinių žodžių vartojama per daug. Jeigu turima tarptautinių žodžių lietuviškų atitikmenų, patariama geriau juos ir vartoti. Lietuvos Respublikos įstatymų ir kitų teisès norminių aktų rengimo tvarkos įstatymo (Valstybės žinios, 1995, Nr. 41-991) 12 straipsnyje, reglamentuojančiame teisès akto kalbą, nurodyta, kad „tarptautiniai žodžiai vartojami tik tada, kai lietuvių kalboje nèra šių žodžių atitikmenų“. Tuo reiketų vadovautis ir ịstatymų leidejjams.

Daugèja tarptautinių žodžių, ateinančių per kalbą tarpininkę. Seimo narių viešojoje sakytineje kalboje gausẻja tarptautinių žodžių, plintančių per anglų kalbą. Jie yra kilę iš klasikinių kalbų, dažniausiai iš lotynų kalbos, dar vadinami ir anglolotynizmais. Kai kurie iš jų turi gerų lietuviškų atitikmenų, pvz.: Politikai per tam tikrą laiką turi priimti imperatyvu (= griežtą; ịsakmų) sprendima [„Dèl Lietuvos politinès sistemos"] LTV 2009-04-21; Sutartys tarp žemdirbiu ir prekybininku turi būti imperatyvios (= privalomos; griežtos; būtinos) „Init“ 2009-06-16; Imperatyviai (= Griežtai; Isakmiai) reikalauti, kad pareigūnai būtų gražzinti ị darba, yra teisiškai nepagrịsta LTV 2012-03-02; Daugelis profsajungu siūlymu yra trivialūs (= paprasti; banalūs) BTV 2011-03-21; Jūsu žodžiai aiškūs ir trivialūs (= paprasti) LTV 2010-03-08. 
Kai kurie vartojami lotynizmai vertintini kaip neteiktinos svetimybès, pvz.: Reikètu pagalvoti apie didžiuosius distributorius (= platintojus; skirstytojus), kurie pristato prekes „Init“ 2011-03-02; Svarbiausi - energetikos klausimai, aš [Seimo Pirmininkè] paprašiau, kad prezidentè būtu tokiu koordinatoriumi (= tokia koordinatorè), moderatoriumi (= vadovè) LTV 2012-03-08.

Nevartotini ir lotynų kalbos kilmės žodžiai legitimacija, legitimumas, legitimuoti, legitimus, -a, pvz.: Kyla abejoniu dèl Seimo komisijos [FNTT pareigūnų atleidimo aplinkybèms tirti] legitimumo (= teisètumo; įteisinimo) LTV 2012-03-02; Lietuva pripažżsta, néra dalykų, kuriuos reikèty legitimuoti (= iteisinti) LTV 2010-03-15; Turizmo istatymas legitimus (= iteisintas) LTV 2011-04-12.

Vietoj vartojamo ir parlamentarų lotynų kalbos kilmès žodžio bonusas tinka iprasti finansų, ekonomikos terminai (piniginè) premija; priemoka, priedas; išeitine išmoka, kompensacija, pvz.: Jei klesti verslas, jei valdininkai gerai dirba, tai kodèl nemokèti bonusu (= priedų; priemokų) prie atlyginimų? „Init“ 2009-04-12.

Lotynų kalbos kilmès tarptautinis žodis mediacija Lietuvoje pradètas vartoti reikšme ,trečiosios, ginče nedalyvaujančios šalies (ppr. vieno ar kelių tarpininkų) tarpininkavimas konfliktuojančioms šalims išspręsti ginčą (šeimos, darbo ir pan.) taikiai, be teismo, abiems priimtinu būdu“. Siūlytinas lietuviškas atitikmuo taikinamasis tarpininkavimas, mediatorius, $-\dot{e}$, tarpininkas, $-\dot{e}$, taikintojas, $-a$. Turètume šiuos lietuviškus atitikmenis ir vartoti, pvz.: Mediacijos (= Taikinamojo tarpininkavimo) įstatymas turi büti veiksmingas "Init“ 2011-05-17; Mediacijos (= Taikinamojo tarpininkavimo) principas visiems šeimos nariams, visi būdai turètu būti išméginti „Init“ 201105-17. Pagirtina, kad Seimo posedyje (2011-03-22) buvo svarstomas ne Mediacijos istatymas, bet Taikinamojo tarpininkavimo įstatymas.

Seimo narių viešojoje sakytineje kalboje pastebima ir daugiau tarptautinių žodžių, turinčių lietuviškų atitikmenų. Kitaip tariant, 
dažniausiai vienu tarptautiniu užgožiama ir stumiama iš vartosenos daugelis lietuviškų žodžių, kuriais galima tiksliai išsakyti norimą mintị. Nuolat girdimi veiksmažodžiai (ir su priešdèliais) generuoti, identifikuoti, inspektuoti, komunikuoti, koreliuoti, realizuoti, subsidijuoti, traktuoti ir kt., pvz.: Sugeneravus (= Sukèlus; Sužadinus) visu Seimo nariu mintis LEO LT klausimu galima pasiekti reikiamų rezultatu „Init“ 2009-03-24; Büsite identifikuotas (= pripažintas) kaip apsvaiges darbe, kai pakramtysite kramtomosios gumos, išgersite pertusino „Init“ 2009-03-17; Dalis žmoniu save identifikuoja (= tapatina) su tam tikra pasaulèżiūra LTV 2012-02-01; D. G. politika identifikuojama (= tapatinama) su Vyriausybès antikrizine programa „Lietuvos ryto" tv 2009-04-17; Pateikeme klausimus, susijusius su "Snoro“ inspektavimu (= tikrinimu) LTV 2012-01-25; Norime, kad kultūros ministras komunikuotų (= bendrautų; palaikytų ryšį) su mūsų frakcija LNK 2010-04-04; Koreliuoti (= Sieti) Mokesčiu socialinio draudimo istatymus „Init“ 2009-02-08; Pridètinès vertès mokestis koreliuoja (= siejasi) su mažmenine prekyba „Init“ 2009-04-14; Užteks ir politinio ryžto realizuoti (= igyvendinti) visas programas LTV 2009-03-24; Valstybès politika realizuojama (= igyvendinama) LTV 2011-03-21; Mes subsidijuojame (= remiame) darbo vieta žmonèms, plètojantiems šeimos verslą LTV 2009-04-22; Per krize valstybé subsidijuoja (= remia) smulkiuosius, vidutinius verslininkus LR 2009-03-06; Girdime kolegu traktavimą (= aiškinimą), kad tai koalicijos sutarties laužymas LTV 2012-03-07; Konstitucijos norma traktuoja (= aiškina) vienaip ir kitaip, todel reikia kreiptis i Konstitucini Teisma LTV 2009-02-27; Mano kalbą dèl lito devalvavimo galima ištraktuoti (= išaiškinti, išsamprotauti) visaip LTV 2009-03-09; Per svarstyma buvo nevienodas Švietimo ir mokslo istatymo traktavimas (= aiškinimas) LTV 201103-25; Kai mes unifikuojame (= suvienodiname) darbo sistema, pasunkiname darbo santykius LTV 2009-04-22.

Nemažai tarptautinių veiksmažodžių gali būti paimami iš anglų 
kalbos ir aplietuvinami. Daugeliu atvejų šie veiksmažodžiai yra neįprasti, žeidžia ir lietuvių kalbos normas. Deja, jų vis naujų pastebima ir parlamentarų viešojoje sakytinėje kalboje, nors turima lietuviškų arba iprastesnių tarptautinių atitikmenų, pvz:: Dempinguoja (=Atmeta; Nuvertina) darbo jejga Lietuvoje priimdami dirbti iš trečiuju šaliu LR 2010-03-02; Priimtas Duju istatymas leistu diversifikuoti (= ivairinti; plèsti) dujų tiekima „Init“ 2011-05-17; Istatymo pateikimas yra tai, kad indikuojama (= nurodoma) problema LR 2009-04-17; Seimas šio [Statybos] istatymo pataisas indoktrinavo (= idiegè) „Init“ 2011-04-26; Svarbu, kaip save pozicionuojame (= pristatome; pateikiame), mums būdinga saviplaka LTV 2012-01-11; Testuojamos (= Tikrinamos) tévų pajamos ir pagal tai skiriami vaiko pinigai LTV 2009-02-10.

Istatymų leidejų viešojoje sakytinèje kalboje gana dažnai neįprasta reikšme vartojami lotynų kalbos kilmès daiktavardžiai negatyvas, pozityvas, kurie seniai žinomi kaip fotografijos terminai. Šie daiktavardžiai, matyt, ir dèl anglų kalbos ittakos vartojami vietoj būdvardžių negatyvus, -i, pozityvus, -i (dalykas, reiškinys, nuostata ir pan.); negatyvu, pozityvu. Be to, vartotini ir šių tarptautinių žodžių lietuviški atitikmenys: neigiamas, -a, blogas, - $a$, nenaudingas, -a; neigiamybe, neigiamumas, neigimas, nepritarimas, nesutikimas ir pan.; teigiamas, $-a$, pagrịstas, $-a$, neabejotinas, $-a$, aiškus, $-i$, tikslus, $-i$, naudingas, $-a$, sékmingas, $-a$, palankus, $-i$, pritariamas, $-a$, tikras, $-a$ ir pan.; teigiamybé, teigiamumas, teigimas ir pan. Stebint dabartinę vartoseną, galima teigti, kad tarptautiniai žodžiai neipprasta reikšme linkę ịsigalèti, pvz.: Apie Lietuvą nerašoma su pozityvu (= teigiamai) BTV 2009-02-10; Mokslo institutu jungimas su universitetais yra pozityvas (= teigiamybe், teigiamas, naudingas dalykas) „Init“ 201003-19; Nemanau, kad skleisdamas negatyva (= neigiamus dalykus), susikrausi politini kapitalą BTV 2010-03-29; Švietimo ir mokslo reformoje yra ne tik negatyvas (= neigiamybe; neigiami dalykai), bet ir pozityvo (= teigiamų, naudingų dalykų) LR 2009-04-27. 
Tarptautiniai žodžiai nuo lietuviškų skiriasi ir semantika, ir stilistine verte ${ }^{7}$. Reikètų įsidèmèti, kad net ir vienos reikšmès, kaip sinonimai vartojami tarptautiniai ir lietuviški žodžiai ne visuomet gali pakeisti vienas kitą, nes „tik kontekstas lemia, kurị iš jų tinka

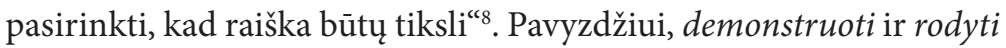
semantiškai nèra tapatūs, todèl juos vartojant ị tai reikètų atsižvelgti. Paprastai žmogus gali ką nors demonstruoti, pvz.: Demonstruoju grafika apie demografine situacija BTV 2010-03-02; Ministras demonstruoja absoliutu neveiklumą LTV 2009-03-04.

Tarptautinis žodis demonstruoti (ir su priešdèliu pa-) imamas vartoti neipprastai, atsiranda ir dviprasmybè, pvz.: Mes [Seimo nariai] turime proga pademonstruoti savo solidaruma susiverždami diržus LTV 2011-03-11; Ministras, mūsų manymu, demonstravo politinę branda LR 2012-03-15; Ministras pademonstravo savo rūpestị Lietuvos žmoniu socialine apsauga LR 2010-02-10. Juk kas kita rodyti ir kas kita demonstruoti (t. y. tyčia, pabrèžiamai) rūpestị Lietuvos žmonių socialine apsauga.

Kartais vartojant minètą tarptautinị žodị žeidžiamos ir lietuvių kalbos normos, pvz.: Mūsų diskusija pademonstravo demagogija, t. y. partijos kalba viena, o daro kita LR 2009-06-13; Seimo Pirmininkes pareiškimas demonstruoja moralines vertybes LTV 2010-02-10. Faktai, duomenys, pavyzdžiai, pareiškimai, diskusijos ir kt. gali ką nors rodyti (arba iš jų matyti), o ne demonstruoti.

Tarptautinių žodžių vartoseną Seimo narių viešojoje sakytinèje kalboje galima vertinti ir kaip norą pasakyti įmantriau arba kaip akivaizdų jų reikšmès nesuvokimą, pvz.: Investuojame ị profesinį mokymąi, tame tarpe (= taip pat) ir $i$ studiju infrastruktūrą LR 201202-02; Mūsu partikuliarinis interesas, kad Rusija išlaikytu gravitacija

${ }^{7}$ Plg. Pikčilingis, J. Lietuviu kalbos stilistika. Vilnius: Mokslas, 1975, t. 2, p. 176-177.

${ }^{8}$ Koženiauskienè, R. Juridinè retorika. Vilnius: Teisinès informacijos centras, 2005, p. 304. 
link Vakaru LTV 2010-07-09; NATO pozicija, komunikatas su Rusija yra neblogas LR 2009-04-07; Padare (= Parengè) konsoliduojanti, apjungiantị (= jungtinị; bendrą) istatymo projekta "Init“ 2011-03-29; Perèjimas $i$ kita mokyklą tampa pozityviai mobilizuojančiu veiksniu, bet yra ir kitu aspektu LR 2010-09-01; Prezentacijoje su kitu metu. biudžeto projekcija socialinio draudimo biudžetas atrodo gerai LTV 2011-10-21; Projektuodami visą pensiju dizaina turime galvoje ir šių dienų pensininką LTV 2011-04-18; Seimas priims rezoliuciją dèl žmogaus teisiu padeties ir situacijos Tibete „Init“ 2009-05-19.

\section{Tarptautinių žodžių semantiniai pokyčiai}

Vienas iš ryškesnių leksikos pokyčių - tarptautinių žodžių vartojimas naujomis, lietuvių kalbai nebūdingomis reikšmėmis. Jeigu ta nauja tarptautinio žodžio reikšmè stumia iš savos kalbos lietuvišką žodi, reikètų suabejoti tos reikšmès tikslingumu. Nemažai tarptautinių žodžių, kaip jau minèta, ateina per anglų kalbą, dažnai per oficialiųjų raštų, dokumentų vertimus. Tarptautiniams žodžiams anglų kalboje vartojamų atitinkamų žodžių pavyzdžiu suteikiama naujų reikšmių. Verčiant iš anglų kalbos ịvairius dokumentus, oficialiuosius raštus paprastai nesigilinama $\mathfrak{i}$ visas vieno ar kito tarptautinio žodžio reikšmes, jis paprasčiausiais neišverčiamas ị lietuvių kalbą. Kita vertus, seniai pripažįstama, kad leksinès reikšmès skirtingose kalbose yra neadekvačios. Taigi paimame ir asimiliuojame iš to paties šaltinio žodžius, bet juos interpretuojame savaip. Be to, reikšmés žodžių, kurie paprastai vartojami kaip atitikmenys, verčiant iš vienos kalbos ị kitą skiriasi vienu ar kitu semantiniu požymiu.

Naujų reikšmių tarptautiniai žodžiai linkę ịsigalèti ir stumia iš vartosenos lietuviškus žodžius. Pateiksime keletą pavyzdžių. Iš graikų kalbos kilmės daiktavardžio harmonija padaryto veiksmažodžio harmonizuoti „Dabartinès lietuvių kalbos žodyne“ (Vilnius: Mokslo 
ir enciklopedijų leidybos institutas, 2000) nurodoma reikšmè - „papildyti melodiją akordais pagal harmonijos taisykles“. Vadinasi, šis žodis vartotinas kalbant apie muziką. „Tarptautinių žodžių žodyne“ (Vilnius: Alma littera, 2004) nurodoma ta pati šio veiksmažodžio reikšmè. Anglų kalboje minètas veiksmažodis turi daugiau reikšmių. „Didysis anglų-lietuvių kalbos žodynas“ (Vilnius: Alma littera, 1998) anglų kalbos veiksmažodžio harmonize rodo dvi reikšmes: 1. (su) derinti; derintis, būti suderintam; 2. muz. harmonizuoti(s). Šia pirmąja anglų kalbos veiksmažodžio harmonize reikšme, kuri yra nebūdinga lietuvių kalbai, tarptautinis žodis harmonizuoti vartojamas ir parlamentarų, pvz.: Ar negalima būtų sudaryti iš Seimo nariu darbo grupę ir harmonizuoti (= suderinti) darbo užmokesčio sistemą? "Init“ 2009-04-21; Bus harmonizuota (= suderinta) duju praktika Europoje „Init“ 2011-05-17; Bus harmonizuota (= suderinta) kainu reguliavimo sistema energetikoje „Init“ 2011-03-15; Europos mastu studiju finansavimo sistema nèra harmonizuota (= suderinta) LTV 2011-05-16; Norètume harmonizuoti (= suderinti) visa alkoholio vartojimo sistema „Init“ 2011-03-22. Taigi turime gražų lietuvišką žodị (su)derinti, kurio negalima pamiršti.

Lotynų kalbos kilmès tarptautinio žodžio konstruoti „Dabartiniame lietuvių kalbos žodyne“ nurodoma reikšmė „kurti konstrukciją“. Tokia pati reikšmė teikiama ir „Tarptautinių žodžių žodyne“ „kurti ko nors konstrukciją, pvz., prietaiso, mašinos, statinio, daryti apskaičiavimus, brèžinius“. „Didžiajame anglų-lietuvių kalbų žodyne" pateiktos trys anglų kalbos veiksmažodžio construct reikšmès: 1. statyti (namą ir pan.); konstruoti (automobili ir pan.); braižyti trikampi; 2. sumanyti, sugalvoti; sukurti; 3 gram. sudaryti (sakinit). Remiantis ir anglų kalboje vartojamo atitinkamo žodžio reikšmèmis tarptautinis žodis konstruoti (ir su priešdèliu su-) parlamentarų viešojoje sakytinejje kalboje vartojamas naujomis reikšmėmis, pvz.: Ekonominès krizès ịveikimo programa konstruojame (= sudarome; 
parengiame) atsižvelgdami i valstybès finansine ir ekonomine padèti LR 2009-03-10; Noréjome, kad biudžetas bütų labiau subalansuotas, negu jūs sukonstravote (= sudarète) LR 2008-04-14; Partijos yra pagrindas, ant kurio konstruojama (= kuriama) demokratine valstybe LTV 2012-01-09; Reikèty atidžiau konstruoti (=formuoti) argumentus dèl aukštosioms mokykloms suteikimo viešuju ìstaigu statuso „Init“ 2009-04-28.

Naujomis reikšmėmis vartojamas tarptautinis žodis konstruoti suteikia dirbtinumo, nepagrịstumo reikšmės atspalvị. Juk kas kita, pavyzdžiui, sukonstruoti bylą ir sudaryti bylą, sukonstruoti biudžeta ir sudaryti biudžetą.

Iš lotynų kalbos kilmès tarptautinio žodžio inkorporacija padaryto veiksmažodžio inkorporuoti „Dabartinès lietuvių kalbos žodyne“ nurodyta reikšmè „ijungti ị sudèti, prijungti“. Ta pati reikšmė „pri(si)jungti, ijungti“ rodoma ir „Tarptautinių žodžių žodyne“. Šia reikšme veiksmažodis inkorporuoti seniai vartojamas lietuvių kalboje. Dabar tarptautinis veiksmažodis inkorporuoti atitinkamo anglų kalbos žodžio incorporate pavyzdžiu vartojamas ir nauja reikšme „îrašyti, ịtraukti“, taip pat ir politikų viešojoje sakytinèje kalboje, pvz.: I gyventojų pajamų mokesčius inkorporuotas (= itrauktas) sveikatos draudimo mokestis LNK 2010-04-20; Pataisas reikia inkorporuoti (= įrašyti; įtraukti) i nutarima „Dèl teisès statuto straipsnių pakeitimo" "Init“ 2009-06-22; Vienas istatymas, i ji inkorporuotos (= itrauktos; ịrašytos) pataisos „Init“ 2011-03-29.

Lotynų kalbos kilmės tarptautinis žodis aspektas lietuvių kalboje vartojamas atžvilgio, požiūrio reikšme. Šio žodžio reikšmė nepagrịstai plečiama gal ir atsižvelgiant ir ị anglų kalbos žodžio aspect platesnę reikšmę. Vis dėlto ir Seimo nariams nereikètų vartoti tarptautinio žodžio aspektas reikšmėmis žodžių duomuo, faktas, įvykis, atvejis, reiškinys; požymis, ypatybe, pvz.: Mažesnèse mokyklose, kuriose to paties amžiaus vaikai, mažiau patyčiu, pastumdymų ir kitu aspek- 
tų (= atvejų; reiškinių) „Init“ 2010-03-23; Sveikatos apsauga turi daug problemu, o Nacionalinio kraujo centro veikla - viena iš aspektų (= duomenų, faktų; požymių) BTV 2010-02-10; Užsienio žiniasklaidoje nèra tų aspektų (= duomenų, faktų; reiškinių; požymių), kurie aktualūs Lietuvai LTV 2010-04-20.

Kartais tarptautinis žodis aspektas pavartojamas taip, kad net sunku suvokti, kas norima pasakyti, pvz.: Didele dalis aspektu pačiu mokyklu rankose LR 2010-09-01; Reikia ieškoti vaiko sèkmès aspekto LR 2010-09-01.

Pagal lietuvių kalbos normas deleguoti galima tik asmenis, bet ne funkcijas, pareigas, igaliojimus, kompetenciją, teises, atsakomybę ir kt. Taigi lotynų kalbos kilmés žodis deleguoti nevartotinas su žodžiais, kurie nereiškia asmens. Gal ir dẻl anglų kalbos atitinkamo žodžio delegate reikšmès minètas tarptautinis žodis vartojamas reikšmėmis „suteikti, perduoti“ taip pat ir parlamentarų, pvz.: Apskričiu reforma vykdoma skubotai, neaišku, kokios funkcijos deleguotos (= perduotos) savivaldybems "Lietuvos ryto“ tv 2010-03-21; Ar prezidentas turi naudoti jam deleguojamus (= suteikiamus) igaliojimus? LTV 2009-03-16; Ministeriju vadovai turi jausti atsakomybe už gera visos ministerijos darbą, nes jiems deleguota (= suteikta) šita funkcija LR 2010-04-09; Pareigas ar funkcijas reikia deleguoti (= perduoti) kitam žmogui, jei buvo nepateisinti lūkesčiai BTV 2009-03-10; Savivaldybei deleguota (= perduota, suteikta) funkcija išlieka "Init“ 2011-05-17; Sveikatos apsaugos ministerijai deleguota (= suteikta) teisé parengti pinigu banka LTV 2011-05-06.

Neịprastai vartojamas dalyvis motyvuotas, - $a$. Šis dalyvis vartojamas kalbant apie asmenį, t. y. vertinant žmogų, dažniausiai vienos ar kitos srities specialistą, valdininką, pareigūną, politiką ir kt. Šiuo atveju dalyvio motyvuotas, - $a$ reikšmè sietina su „Tarptautinių žodžių žodyne" rodoma lotynų kalbos kilmès daiktavardžio motyvacija pirmąja reikšme - „tam tikro elgesio, veiklos, paskatų, motyvų 
turejjimas“, t. y. „kuris turi paskatų, motyvų dirbti tam tikrą darbą, atlikti tam tikras pareigas“. Kitaip tariant, „kuris atsidavęs darbui“. Tiktų vartoti (kartais tai pastebima) turintis, -i motyvacija arba atsidavęs, -usi, specialistas, -é, valdininkas, $-\dot{e}$, pareigūnas, $-\dot{e}$, politikas, $-\dot{e}$ ir kt. Neipprastos, žeidžiančios lietuvių kalbos normas dalyvio motyvuotas, -a vartosenos turètų vengti ir parlamentarai, pvz.: Dauguma motyvuotų (= turinčių motyvaciją) žmonių gali rinktis geresnès kokybès aukštąsias mokyklas LTV 2012-01-11; Mes galime pasirinkti motyvuotus (= turinčius motyvaciją; atsidavusius) mokytojus LTV 2012-02-26; Reikia padaryti (= pasiekti), kad žmogus būtų motyvuotas (= turètų motyvaciją) dirbti LTV 2009-12-28.

Tokia dalyvio motyvuotas, - $a$ vartosena yra ne kas kita, kaip vertimas iš anglų kalbos. Pagal lietuvių kalbos normas žmogus negali būti motyvuotas, jo gali būti motyvuotas arba pagrịstas elgesys, darbas; motyvuota arba pagrịsta veikla; motyvuoti arba pagrịsti veiksmai ir pan.

Linkstama vartoti dalyvị motyvuotas, - $a$ ir su lotynų kalbos priešdèliu de-, pvz.: Dar daugiau demotyvuotų (= neturinčių motyvacijos) žmonių, kaupiančiu savo lěšas Pensijiniuose (= Pensijų; Pensiniuose) fonduose TV3 2011-12-07; Kai kurie demotyvuoti (= neturi motyvacijos) dirbti už vergišką atlyginimą Lietuvoje BTV 2011-0510. Kartais prireikia net dviejų priešdèlių, pvz.: Didžiojoje Britanijoje aukštosiose mokyklose jaunimo nedemotyvuoja (= neskatina?) mokytis blogiau, linkiu Lietuvos aukštosiose mokyklose sukurti tokia aplinka LTV 2012-01-11. Tokią vartoseną, jau nekalbant apie lietuvių kalbos normų pažeidimus, galima vertinti ir kaip įmantravimą, norą kalbèti kitoniškai. 


\section{Neteiktini vertiniai}

Seimo narių viešojoje sakytinejje kalboje pastebima neteiktinų vertinių, nemažai iš rusų kalbos, pvz.: Kažkas neteisingai ịtakoja (= daro įtakos; veikia) mūsu prezidentę LTV 2012-03-02; Suprate, kad šilumos kaina labai ịtakoti (= veikti; daryti kainai itakos) negalime, bet pateike pataisas galime ja sumažinti iki 20 proc. "Init“ 2011-03-29; Recesijos metu, kaip taisykle,, (= paprastai; dažniausiai) kainos èmé mažèti LT 2009-03-06; Tas [būstų renovavimo] modelis pasirodo, kaip taisykle, (= paprastai; dažniausiai) buvo naudingas bankams LTV 2011-03-29; Kas liečia infliaciją, (= Kalbant apie infliaciją; Dèl infliacijos; O dèl infliacijos) finansu ministras sprendžia (= nagrinèja) daugeli iškilusių klausimų LTV 2009-05-04; Kaip nekeista (= Keista, Kad ir kaip būtų keista), prieš paskelbiant išvadas [Seimo komisijos dèl pareigūnų atleidimo aplinkybių tyrimo] narių nepadaugejjo BTV 2012-03-08; Ar mes galime kažka tai (= kažką) patys susitvarkyti viduje? LTV 2012-03-21; Kažkaip tai (= Kažkaip) neatstovauja rinkejjams "Init“ 2011-04-12; Duotu atveju (= Šiuo atveju) dauguma klausimu priklauso nuo politinés valios LTV 200905-04; Ne prie ko čia (= Niekuo dèti) prezidento rinkimai, aš niekad neleisčiau tokio biudžeto "Init“ 2009-04-14; Reikètų juvesti laisvanorišku (= savanoriškų) rinkimu principa "Init“ 2011-03-22; Šis nutarimas [„Dèl valstybinio socialinio draudimo ir pensijų pertvarkos“] yra savalaikis (= laiku priimtas) „Init“ 2011-04-12.

Kai kurie Seimo nariai neišvengia žodžių ir žodžių junginių reikšmès klaidų, arba vadinamųjų semantinių vertinių, pvz.: Prezidentès patarèjai padèjo nuimti (= atleisti; pašalinti) FNTT pareigūnus LNK 2012-03-18; Valstybé uždeda mokesčius (= apmokestina; skiria mokesčius), galvoja, kad mokés pensijas ir algas „Init“ 2011-03-22; Akcininkai neša vienodą atsakomybę (= vienodai atsako, vienodai atsakingi) LTV 2012-01-27; Pilnai (= Visiškai) pritarčiau, kad nereikia 
tyčiotis, ironizuoti BTV 2012-03-08; Siūlau pilnai (= išsamiai) svarstyti ši [energetikos] klausima "Init“ 2011-03-15; Ne politiniu pareigybiu gausa apsprendžia (= lemia) savivaldybiu darba "Init“ 2011-0315; Buvo spaudžiama, kad ìmonejje būtu pravestas (= suorganizuotas; surengtas) konkursas „Init“ 2011-09-02; Klausimas [dèl valstybinių miškų] apima platu ratą (= daug; daugelį; daugybę) suinteresuotų žmoniu „Init“ 2011-03-29; Gal pajungsime (= itrauksime) partijas, kuriu vadai nesurinko balsu „Lietuvos ryto“ tv 2009-04-17.

Paprastai aptarnauti galime asmenis, o visa kita turètume tvarkyti, administruoti. Taigi ir Seimo nariai turètų laikytis šių lietuvių kalbos normų, pvz.: Kiek kainuoja kasos aparatu aptarnavimas (= tvarkymas)? „Init“ 2011-03-22; Lenkijos skolos aptarnavimas (= tvarkymas) yra sunkiai pakeliamas LTV 2009-03-17; Mes norime irodyti savo skolininkams, kad esame patikimi partneriai, kad skola galime aptarnauti (= tvarkyti) LR 2010-03-02. Taip pat vartotina ne aptarnaujanti imo$n \dot{e}$ (ịstaiga ir kt.), bet prižiūrinti įmone (ịstaiga ir kt.).

Daugejja neteiktinų vertinių iš anglų kalbos. Kai kurie iš jų linkę ìsitvirtinti ir kaip terminai. Atsirado dukterine įmoné (plg. angl. daughter enterprise), vèliau ir motinine imoné (plg. angl. mother enterprise). Taip pat pradèti vadinti ir bankai, savivaldybes, ir kt. Lietuviu kalboje turime atitikmenis antrinis, $-\dot{e}$ (imoné, bankas, savivaldybe ir kt.) ir pagrindinis, - $\dot{e}$ (imonè, bankas, savivaldybè ir kt.), vartosenoje pastebèta ir pirminis, - $\dot{e}$ (imonè, bankas, savivaldybė ir kt.). Taigi ir įstatymų leidejjai turètų vartoti šiuos atitikmenis, pvz.: Motininiai (= Pagrindiniai) bankai yra Skandinavijoje BTV 2009-02-10; Motininiai (= Pagrindiniai) bankai turètų veikti tomis pačiomis salygomis, kaip ir dukteriniai (= antriniai) LT 2009-03-02; Mes turésime motinines (= pagrindines) savivaldybes, kurios norès ribotis su mažesnèmis „Init“ 2009-03-17; Svarbu, kad motininiai (= pagrindiniai) bankai nediskriminuotu dukterinių (= antrinių) banku, kad nereikalautu, jog pinigais nebūtų naudojamasi nacionalinèse rinkose „Init“ 2009-03-17. 
„Dabartiniame lietuvių kalbos žodyne“ teikiamos šešios veiksmažodžio matyti reikšmès: 1. akimis pagauti daikto vaizdą, rege்ti; 2. pastebèti; 3. suprasti, suvokti; 4. patvirtinti; 5. sutikti; 6. prk. gauti. „Didžiajame anglų-lietuvių kalbų žodyne“ nurodoma daugiau kaip šešiolika atitinkamo anglų kalbos veiksmažodžio see reikšmių. Be minètų „Dabartiniame lietuvių kalbos žodyne“, šio anglų kalbos veiksmažodžio dar rodomos reikšmès: apžiūrèti; isivaizduoti; vaidentis; sužinoti; pažiūrèti, išsiaiškinti; tartis, konsultuotis; (pa)lydèti; pasirūpinti; pažiūrèti; prižiūrèti; issigilinti ir kt. Taigi ir lietuvių kalbos veiksmažodžiui matyti ir jo abstraktui matymas suteikiama ir šių svetimų reikšmių. Apskritai jie vartojami per dažnai, taip pat ir Seimo narių, lyg nebūtų lietuvių kalboje kitų žodžių norimai minčiai pasakyti; pvz.: Aš [Seimo Antikorupcijos komisijos pirmininkas] pakomentuosiu savo matyma dèl Seimo nariu išejimo iš Seimo komisijos [Dèl FNTT vadovų atleidimo aplinkybių tyrimo] LR 2012-03-02; Liberalai turi viena matyma, konservatoriai - kita LTV 2010-03-08; Mano [Seimo Socialinių reikalų ir darbo komiteto pirmininko] $\mathrm{ma}$ tymas yra toks, kad nepagrista teigti, jog reikès mažinti pensijas LR 2009-04-20; Mes nepasieksime bendro matymo su Rusija, bet nereiškia, kad neturime diskutuoti LR 2009-04-07; Mūsų [socialdemokratų] matymas yra tas, kad šitu [energetikos] sektoriu turètu valdyti valstybe் LTV 2011-06-10; Mūsu partijos „Viena Lietuva“ matymas būtų toks: ryte sakoma viena, vakare daroma kita LTV 2010-02-10.

Kartais prieinama ir prie visiškai absurdiško vartojimo, pvz.: Mes [socialdemokratai] matome ir savo matyma, kaip spręsti problemas valstybeje LTV 2011-06-10.

Pastebima, kad parlamentarai po neaiškia reikšme pavartoto abstrakto matymas suranda ir teikia kitą tikslesnị žodị, pvz.: Aš [Seimo Socialinių reikalų ir darbo komiteto pirmininkas] kalbu apie savo matymą, savo požiūrị LR 2009-04-20; Aš [Seimo Pirmininkè] išsakau savo matyma, ižvalgas LTV 2011-05-16; Bet kuriuo svarstomu klau- 
simu aš [Seimo narys] pateikiu savo matymą, t. y. savo viziją TV3 2009-04-17.

Žeidžiamos lietuvių kalbos normos, kai abstraktas matymas vartojamas daugiskaitos forma, pvz.: Jeigu bus neatsižvelgta i mūsu [partijos „Viena Lietuva“] matymus, apie joki prisijungima negali būti jokios kalbos LTV 2010-02-10; Svarbu susitarti dèl Vyriausybès bendru. matymy LTV 2010-02-10.

Apskritai ryški tendencija - nusitverti vieną ar kitą žodị, vartoti visiškai negalvojant, kur jie tinka ar netinka. Tokiu atveju ir stilistiškai nuvalkiojami lietuviški ir tarptautiniai žodžiai, skurdinama ir pati lietuvių kalba. Itin dažnas ne pagal paskirtį vartojamas ir žodis pakankamai. Ši žodi taip pat pamėgo Seimo nariai, pvz.: Antra krizès banga ìveikème pakankamai išmintingai LR 2011-12-27; Buvo pakankamai ilgos ir sudetingos diskusijos „Init“ 2011-03-29; Yra pakankamai dideles investicijos, universitetai persiorientuoja $j$ studentu. poreikius, Lietuvoje yra iš ko pasirinkti LTV 2012-02-26; Jei pažeidei tvarka, turi būti pakankamai griežti reikalavimai „Init“ 2011-03-29; Lietuviams pakankamai malonu mètytis i viena ar i kita pusę "Init“ 2011-03-29; Matome pakankamai prieštaringus požiūrius LTV 2011 04-26; Norima geriau gyventi kitu saskaita, su tuo mes pakankamai dažnai susiduriame LTV 2011-04-11; Rinko informacija apie generalinio prokuroro pavaduotoja pakankamai ilgai LTV 2012-03-04; Šitas istatymas ["Dèl žemès paèmimo visuomenès poreikiams"] pakankamai aiškus „Init“ 2011-03-29; Teisinèje valstybejje pakankamai sunku padaryti kai kuriuos sprendimus „Init“ 2011-03-29; Vyriausybe iveike pakankamai sudetingus metus LR 2011-12-27.

Visur kaišiojant pakankamai perkraunami sakiniai, temdoma mintis. Atsiranda visiškai dirbtinių, griozdiškų sakinių, pvz.: Pakankamai neprincipingai per daug padaryta kai kurių išlygu dèl šilumos ūkio „Init“ 2011-03-29. Žinoma, neišvengiama ir dviprasmybès, pvz.: Generalinè prokuratūra darè pakankamai nemažai veiksmų, kad būtų 
islaptinta medžiaga LTV 2012-03-04; Kai kurie žmonès pakankamai mažai uždirba LTV 2011-04-04. Taigi neaišku, ar Generalinė prokuratūra darè pakankamai veiksmu, ar nemažai veiksmų; taip pat negalima suprasti, ar kai kurie žmonès pakankamai uždirba ar mažai uždirba. Arba, pvz.: Prokurorai pakankamai daug sunerime, tai vadinasi, kažkas negerai LTV 2011-04-01. Gal prokurorai labai sunerimę?

Vadinasi, prieš vartodami žodị pakankamai ir Seimo nariai turètų pagalvoti, ar iš viso jo reikia norimai minčiai pasakyti. Be to, reikètų prisiminti ir kitų ta pačia reikšme vartotinų žodžių: gana, ganètinai, užtektinai, sočiai, kaip reikiant ir kt.

\section{Gramatinès formos ir vartosena}

Seimo narių viešojoje sakytinèje kalboje pastebima lietuvių kalbos sintaksès normų pažeidimų. Nemažai linksnių vartojimo klaidų. Ypač krinta ị akis netaisyklingas vietininko linksnio vartojimas, pvz.: Aš [Seimo narys] priimsiu sprendima savo kompetencijos lauke (= pagal savo kompetenciją) LTV 2012-04-18; Jis [aplinkos apsaugos ministras] savinasi pirmoje eileje (= pirmiausia) nuveiktus darbus LTV 2011-11-26; Pirmoje eileje (= Pirmiausia; Pradžioje) reikia paaiškinti žmonèms, kam pinigai skiriami LTV 2011-03-04; Mums mažai rūpi jaunu žmonių, tame tarpe (= taip pat; tarp jų) ir lenkų ateitis LTV 2011-03-25; Reikia atrasti formuluotes, tame tarpe (=taip pat) neiškraipant ir Konstitucinio Teismo nuostatu LTV 2012-01-11; Kame reikalas (= Koks reikalas; Kas yra; Kas nutiko), kodèl reikia mažinti akcizus alkoholiniams gérimams? „Init“ 2011-03-22; Sukiršinsime visuomene, kuri ir taip yra jautrioje būsenoje (= jautrios būsenos) „Init“ 2011-04-12; Norime inicijuoti pokyčius pedagogu rengime (= rengiant pedagogus) LR 2010-09-01.

Netaisyklingai vartojamas naudininko linksnis, pvz.: Šiai dienai (= Šiandien; Šią dieną; Iki šios dienos) Vyriausybe nieko neveikia 
"Init“ 2009-03-17; Šiai dienai (= Šiandien; Šią dieną) Prezidento institucija tapo psichologiniu veiksniu LTV 2009-03-16; Ar pakankamai konkuruojama premjerui (= su premjeru)? LTV 2011-04-12.

Parlamentarai daro ir prielinksnių vartojimo klaidų, pvz.: $D a-$ bar polinkis kalbèti daugiau ant emocijų (= emocingai; emocijomis) LR 2009-04-20; Jei kas žais ant emocijų (= emocijomis), bus dar didesne painiava reformuojant "Sodra“ BTV 2011-03-02; Kas daroma ant Lietuvos (= Lietuvoje), visi keikia sovietmeti, bet taip nebuvo „Init“ 2011-04-19; Dél šilumos mazgu eksploatavimo pas nieka nèra (= niekas neturi) kitos nuomones „Init“ 2011-03-29.

Reikètų vengti polinksnio atžvilgiu, pvz.: Kuriu studentų at$\check{z}$ vilgiu (= Kuriems studentams) bus taikomos Konstitucinio Teismo nuostatos, tuoj išaiškès LTV 2012-01-12.

Seimo narių viešojoje sakytinejje kalboje pastebima ir morfologinių formų vartojimo klaidų. Netaisyklingai vartojama veiksmažodžių bendratis, dalyviai ir kt., pvz.: Kad išgirsti (= Kad būtų išgirsta), reikia tinkamai pateikti LTV 2009-03-16; Kad išvengti (= būtų išvengta) kolizijų, reikia daryti pertrauka svarstant ši [Administracinių teisių pažeidimų] istatymą „Init“ 2011-03-29; Kad išvengti (= būtų išvengta) spekuliacijos, reikia paimti žemę tokia kaina, kokia isigijo savininkas „Init“ 2011-03-29; Dèl atmetimo [įstatymo] sprendžia ne pirmininkaujantis (= pirmininkas) „Init“ 2011-03-29; Pirmą vedanti (= pagrindini) istatyma mes atidejome svarstyti „Init“ 2011-03-29; Tikiu, kad sprendima priimsite vedini (= vedami) ne tik politiniu išskaičiavimu LTV 2011-03-29.

Neišvengiama žodžio sandaros klaidų, netaisyklingos darybos formų, ypač žodžių su priesagomis. Seimo narių viešojoje sakytinèje kalboje nemažai būdvardžių su priesaga -inis, $-\dot{e}$ darybos ir vartojimo klaidų, pvz.: Bankuose dominavo spekuliatyviniai instrumentai (= spekuliacinès priemonès) LR 2009-04-03; Spekuliatyviniai (= Spekuliaciniai) dalykai LTV 2011-04-04; Ar reikia žaisti pensi- 
jinèmis (= pensijų; pensinèmis) kortomis rinkimuose? BTV 2011-0322; Ar tikrai privalomi pensijiniai (= pensijų; pensiniai) fondai turètu egzistuoti? „Init“ 2011-05-17; Privačių pensijinių (= pensijų; pensinių) fondu veikla nèra pagrista LTV 2011-04-18; Mes prièméme mokestinę (= mokesčių) reforma su biudžeto mažinimu, kur ta riba, kai nustosime mažinti biudžetą? "Init“ 2009-04-14; Turètume apsvarstyti geriausią mokestinių (= mokesčių) istatymu variantą "Init“ 2009-0208; Šiandien ịstatyminè (= teisinè; ịstatymų) bazè neleidžia paežerèse apsitverti tvoromis „Init“ 2011-03-29; Europiniai renginiai - normalus derybinis (= derybų) procesas LTV 2011-04-11.

\section{Leksikos vartosena ir kalbos etika}

Parlamentarai turètų nepažeisti ne tik bendrinès lietuvių kalbos normų, bet ir etikos normų. Pasak Reginos Koženiauskienès, „iš tiesų neįmanoma skirti elgsenos ir kalbos, nes politiko etika - tai apeliacija ị jo elgseną apskritai (taigi ir ị kalbinę elgseną). Nuolat girdimi ir matomi politikai yra viešosios pavyzdinès kalbos formuotojai, pašaukti vartoti pačią korektiškiausią kalbą. Turbūt nẻ nereikia sakyti, kad kalbos korektiškumo sąvoka apima ne tik taisyklingumo, bet ir gana griežtus moralinius reikalavimus, atsakomybę už savo poelgius ir kalbą"9. Vis dèlto atsainiai žiūrima į etikos normas, nepaisoma ir kalbos etikos. Apskritai dabartinès visuomenės ryškus polinkis ị agresyvumą, kito žmogaus menkinimą. Tai pastebima ir iš kai kurių ịstatymų leidejjų viešosios sakytinès kalbos, ypač iš jų vartojamos leksikos. Per Seimo posėdžius ir apskritai jų viešosiose kalbose girdima vulgarių, užgaulių žodžių pusprotis, - $\dot{e}$, subinlai$\check{z} y s,-\dot{e}$, subinlaižiavimas, savotiškas keiksmažodis nafik ir kt., pvz.: Nieko negaliu pasakyti, puspročiai [apie iš FNNT atleistus vadovus]

${ }^{9}$ Koženiauskienė, R. Politinė retorika etiniu požiūriu. Parlamento studijos. Vilnius: Lietuvos nacionalinè Martyno Mažvydo biblioteka, 2005, Nr. 3, p. 110. 
LNK 2012-02-14; Laikas baigti su tuo subinlaižiavimu, jokio Kinijos griovimo nèra [svarstoma Seimo rezoliucija „Dèl Tibeto problemų sprendimo“] „Init“ 2009-03-17; Reikejjo ne ikkasti premjerui i uodega, o nukąsti BTV 2012-03-08.

Reiškiamas atitinkamas požiūris ir vartojant žodžius perkeltinèmis reikšmėmis. Siekiant pasakyti aštriau, užgauliau, jૃžūliau, dažnai perkeltinėmis reikšmėmis vartojami medicinos terminai, pvz.: Vyriausybès nariai elgiasi kaip politiniai autistai „Init“ 2009-05-06; Ar miškininkai yra impotentai, kad negali priimti istatymu?? „Init“ 2011-03-29; Ǎ̌ [Seimo narys A. B.] paranoja dar nesergu „Init“ 2011-03-29; Mes [Seimo nariai] neturime teisés skleisti įtarumo ir paranojos „Lietuvos ryto“ tv 2010-10-15.

Kai kurie ipprasti žodžiai linkę gauti neigiamas konotacijas, juos vartoja ir Seimo nariai, pvz.: gaidys, (riebus) katinas, kurmis, neigiama reikšme vartojama proto bokštas ir kt. Šie žodžiai igauna menkinamosios reikšmės atspalvių, pamenkinami ir jais pavadinti žmonès. Apskritai „konotacinè reikšmè - žodžio informacija apie emocini kalbos vartojimo santyki su vadinamuoju dalyku“"10.

Pastebima, kad menkinamos ir pamatinès vertybès. Pavyzdžiui, niekinamąja reikšme kai kurie Seimo nariai vartoja ir pasakymą Lietuva - Marijos žemé. Gailestingoji Mergelè Marija, Dievo Motina pasidaro ne tik vilties žvaigždè, bet ir banalumo, menkinimo simbolis, pvz.: Kitoje šalyje tai [dèl rugsejjo pirmosios skelbimo nedarbo diena] būtu padaryta paprastai, bet Lietuva yra Marijos žemé, todel viska reikia daryti per ịstatyma (= remiantis istatymu) LR 2010-08-24; Lietuva yra Marijos žemé, todel viskas atrodo kitaip LTV 2011-04-01.

${ }^{10}$ Lietuviu kalbos enciklopedija. Parengè K. Morkūnas; sudarè V. Ambrazas. Vilnius: Mokslo ir enciklopedijų leidybos institutas, 1999, p. 327. 


\section{Išvados}

Parlamentarų viešosios sakytinès kalbos duomenų analizė rodo:

1) globalizacija ir su ja susiję kiti ekstralingvistiniai ir interlingvistiniai veiksniai, ypač anglų kalba, turi įtakos vartojamos leksikos pokyčiams;

2) imama vartoti daugiau skolinių, ateinančių iš anglų kalbos arba per anglų kalbą; trikdoma lietuviškų ir svetimų kalbų žodžių vartojimo pusiausvyra;

3) tarptautiniams žodžiams suteikiama naujų, lietuvių kalbai nebūdingų reikšmių, paremtų atitinkamų anglų kalbos žodžių reikšmèmis;

4) randasi neteiktinų vertinių, daugèja jų ir iš anglų kalbos;

5) vartojama neteiktinų gramatinių formų: sintaksès, morfologinių, žodžių darybos;

6) Žeidžiamos bendrinès lietuvių kalbos normos, kalbos etika;

7) Seimo nariai turi norèti puoselèti valstybinę lietuvių kalbą kaip nacionalinę vertybę, kelti lietuvių kalbos prestižą. 


\title{
REGARDING PUBLIC ORAL SPEECH DELIVERED BY THE PARLIAMENTARIANS
}

\author{
VIDA RUDAITIENE்
}

\section{Summary}

Keywords: extra-linguistic factors, inter-linguistic factors, borrowing, international word, language ethics, connotational meaning.

The aim of article is to analyze the public oral speech delivered by the parliamentarians. It is also aimed to discuss the used lexis of the Lithuanian language and foreign languages, the changes of its usage, to raise more meaningful extra-linguistic and inter-linguistic factors determining these changes; to analyze the influence of the English language as one of the factors of globalization on public oral speech, especially on the usage tendencies of the borrowings; to analyze more pronounced usage maladies of underemphasized translations and grammatical forms: syntax, morphologies, word formation; to evaluate oral language delivered by parliamentarians not only in the aspect of general Lithuanian language norms, but also in the aspect of language ethics. Also, one of the objectives raised is to encourage parliamentarians cherish the Lithuanian language, to raise the prestige of the Lithuanian language.

The main source of speech data is the public oral speech delivered by the parliamentarians, sessions of Seimas often broadcasted on the Lithuanian television, political discussion, commentary, conversation, conference and other shows broadcasted on the Lithuanian television.

The analysis of speech data of the public oral speech delivered by the parliamentarians shows that globalization and other related extra-linguistic and inter-linguistic factors, especially the English language, have influence to the changes of the lexis used, more borrowings are started to be used coming from the English language and through English language, the balance of usage of Lithuanian and foreign languages is undermined; Internationalisms receive new meanings not characteristic to the Lithuanian language, based on specific meanings of the words of the English language; there emerge underemphasized translations also from the English language; underemphasized grammatical forms are used: syntax, morphology, word formation, etc.; general norms of the Lithuanian language as well as language ethics scotched.

Iteikta $2012 \mathrm{~m}$. balandžio $26 \mathrm{~d}$. 